\title{
Autoimmune hepatitis type 2 associated with an unexpected and transient presence of primary biliary cirrhosis-specific antimitochondrial antibodies: a case study and review of the literature
}

Pietro Invernizzi ${ }^{1} 2^{2 *}$, Maria Grazia Alessio ${ }^{3}$, Daniel S Smyk ${ }^{4}$, Ana Lleo ${ }^{1}$, Aurelio Sonzogni ${ }^{5}$, Luca Fabris ${ }^{6,7}$, Manila Candusso ${ }^{8}$, Dimitrios P Bogdanos ${ }^{4}$, Raffaele lorio $^{9}$ and Giuliano Torre ${ }^{8}$

\begin{abstract}
Background: Unlike other autoimmune liver diseases, primary biliary cirrhosis (PBC) has never been reported in early childhood, while type 2 autoimmune hepatitis (AIH) is eminently a paediatric disease.

Case presentation: We describe a case of type $2 \mathrm{AlH}$ with serological positivity for PBC-specific anti-mitochondrial antibodies (AMA) in a 3-year old girl. We found this observation intriguing as AMA and indeed an overlap with PBC are virtually absent in Type $2 \mathrm{AlH}$, a pediatric form of $\mathrm{AlH}$ which is distinct precisely because it is characterized by pathognomonic anti-liver kidney microsomal type 1 (LKM-1) showing a remarkable antigen-specificity directed against cytochrome P4502D6. We also review the literature in relation to AMA positivity in paediatric age and adolescence. In our case, the presence of AlH-2-specific anti-LKM-1 and PBC-specific AMA was confirmed by indirect immunofluorescence (IIF), and immunoblotting and ELISA based on recombinant mitochondrial antigens. The clinical, laboratory and histological features of the child are given in detail. Interestingly the mother was AMA positive without other features of PBC. The child was successfully treated with immunosuppression and five years after the original diagnosis is on a low dose of prednisolone and azathioprine, with no signs of relapse. Anti-LKM-1 antibodies are still present in low titres. AMA were detectable for the first 4 years after the diagnosis and disappeared later.

Conclusion: This is the first case report in the literature of AlH type 2 with an unexpected PBC-specific AMA positivity in a young child. Response to immunosuppressive treatment was satisfactory and similar to that described in AlH. A review of published reports on AMA positivity in paediatric age shows that the antibody may arise in the context of immunodeficiency and is variably associated with liver damage.
\end{abstract}

Keywords: Autoantibody, Autoimmunity, Autoimmune cholangitis, Epidemiology, Environment, Paediatric liver diseases.

\footnotetext{
*Correspondence: pietro.invernizzi@humanitas.it

${ }^{1}$ Center for Autoimmune Liver Diseases, Humanitas Clinical and Research

Center, Via Manzoni 56, 20089 Rozzano(MI), Italy

${ }^{2}$ Division of Rheumatology, Allergy and Clinical Immunology, University of

California at Davis, Davis, CA, USA

Full list of author information is available at the end of the article
} 


\section{Background}

Primary biliary cirrhosis (PBC) typically affects middle aged women and has never been reported in previously healthy young children, although affected adolescents have been described [1-22]. The disease is characterized by an immune-mediated destruction of intrahepatic bile ducts and the presence of high-titer anti-mitochondrial antibodies (AMA) against the E2 subunit of the pyruvate dehydrogenase complex (PDC-E2) [3,9,11-13,23-39]. AMA are highly specific for $\mathrm{PBC}$, and can be detected in approximately $95 \%$ of patients when sensitive diagnostic immunoassays are used [3,6,9,11-13,18,21,23-38,40-50]. The etiology of the disease remains elusive, but is believed to derive from a combination of factors including a multi-lineage loss of immunological tolerance to PDC-E2 [10,13,15,16,29-31,33,36,43-45,51-84], genetic susceptibility $[6,9,11,22,51,77,85-111]$ and exposure to environmental triggers [51,52,58,112-135]. Descriptive epidemiological studies strongly suggest that the incidence and prevalence of PBC are increasing [136-140].

We herein describe the unusual case of a 3-year-old girl with overlapping autoimmune hepatitis type 2 (AIH-2) and PBC-specific AMA positivity. She presented with acute liver failure with no evidence of infections, metabolic and genetic liver disease or other causes of acute liver disease. The autoantibody testing revealed the presence of anti-liver kidney microsomal antibodies (LKM-1) and PBC-specific AMA, the autoantibody markers of AIH-2 and PBC, respectively. Though histological findings did not demonstrate typical overlap of $\mathrm{PBC}$ and $\mathrm{AIH}$, they were compatible with both $\mathrm{AIH}$ and overlapping biliary features. AMA were also detected in the mother's serum samples.

Over a seven-year period, 3808 paediatric patients with liver disease were screened in a single tertiary center in Northern Italy, Bergamo, for the presence of serum autoantibodies. The screening program included children with acute or chronic liver diseases in the course of evaluation for inclusion onto a waiting list for orthotopic liver transplant (OLT), or during follow-up after OLT. Throughout that period, 340 paediatric OLT were performed. Out of 3808 tested patients, only 2 tested positive for AMA by indirect immunofluorescence (IIF), which was confirmed by western blot with recombinant antigens. The first one presented with acute liver failure (ALF) with massive hepatic necrosis, was transplanted and spontaneously lost AMA after OLT. The second one is herein described. To our knowledge, this is the first child with AIH type 2 and AMA positivity documented at the level of individual $\mathrm{PBC}$-specific mitochondrial antigens ever reported.

\section{Case report}

SM, a 3-year-old previously healthy girl, came to medical attention because of progressive jaundice, fatigue and anorexia. She was admitted to a local hospital and on examination was found to be icteric with hepatosplenomegaly but no ascites. No prior history of early deaths, liver disease or autoimmunity existed in the family. Laboratory tests indicated cholestatic hepatitis without impaired liver function (Table 1). However, her condition deteriorated within 24 hours with features of acute liver failure (International normalized prothrombin ratio [INR] 2, increasing hyper-ammoniemia from 55 to 105 and up to $196 \mathrm{mMol} / \mathrm{L}$ ) and neurological deterioration. Five days later, she was admitted to the Pediatric Liver Transplant Centre (Ospedali Riuniti, Bergamo) with stage I hepatic encephalopathy. Ultrasound examination demonstrated a hyper-echogenic left hepatic segment with structural alteration, suggestive of chronic parenchymal damage.

Table 1 Routine laboratory results before, at admission and during previous outside hospitalization. Therapy with steroids and cyclosporine was started on day 1

\begin{tabular}{|c|c|c|c|c|}
\hline & $\mathrm{t}=-5$ days & Admission $\mathrm{t}=0$ & $\mathrm{t}=\mathbf{2 0}$ days & $\mathrm{t}=40$ days \\
\hline AST (IU/L) nv $<35$ & 3,700 & 1,243 & 128 & 25 \\
\hline ALT (IU/L) nv $<32$ & 2,800 & 1,249 & 234 & 47 \\
\hline Bilirubin, total (mg/dl) nv $<1.2$ & & 16.90 & 7.90 & 1 \\
\hline Bilirubin, direct $(\mathrm{mg} / \mathrm{dl}) \mathrm{nv}<0.3$ & 10 & 14.60 & 5.50 & 0.60 \\
\hline Albumin $(\mathrm{g} / \mathrm{dl}) \mathrm{nv}<3,5-5 \mathrm{~g} / \mathrm{dl}$ & & 4.20 & 3.66 & 4 \\
\hline INR nv 0.9-1.2 & 2.00 & 2.15 & 1.23 & 1.07 \\
\hline \multicolumn{5}{|l|}{ Immunoglobulins } \\
\hline $\operatorname{lgG}(\mathrm{mg} / \mathrm{dl})$ nv 707-1919 & $\mathrm{nt}$ & 2230 & 1020 & $\mathrm{nt}$ \\
\hline $\operatorname{lgA}(\mathrm{mg} / \mathrm{dl}) \mathrm{nv} 60-270$ & nt & 271 & 136 & nt \\
\hline IlgM (mg/dl) nv 61-276 & nt & 200 & 122 & nt \\
\hline
\end{tabular}

t, time point; nv, normal value; nt, not tested. 
AMA and LKM were strongly positive (> 1:640), and total serum IgG and IgM levels were elevated. The laboratory tests excluded viral infections (hepatitis virus A, B, C, D, human immunodeficiency virus, Epstein-Barr, cytomegalovirus, and herpes simplex virus), metabolic and genetic alterations (Wilson disease, haemochromatosis, and alpha-1 antitrypsin deficiency). Liver biopsy was contraindicated because of the coagulation abnormalities.

Based on the clinical and laboratory findings, i.v. therapy with methylprednisolone (2 $\mathrm{mg} / \mathrm{kg} /$ day) and cyclosporine (continuous infusion at doses of $2-3 \mathrm{mg} / \mathrm{kg} /$ day in order to maintain a blood level up to $300 \mathrm{ng} / \mathrm{ml}$ ) was started. During the following 36 hours, hepatic encephalopathy progressed to stage III and hepatic function deteriorated (Table 1), and the child was listed for urgent OLT. However the child improved in the following days with complete neurological recovery and she was removed from the transplant list. One week after the beginning of therapy, the hepatic function was normal, and steroid tapering was initiated one month later. In the following 3 months, steroids were decreased and cyclosporine was switched to azathioprine (50 mg/day).

Repeated laboratory tests confirmed the presence of both anti-LKM-1 antibodies by IIF (Figure 1) $[48,141,142]$ and AMA by western blot with recombinant antigen [13] (Figure 2) over a two year period. Seropositivity for $\mathrm{PBC}$-specific autoantibody responses were also confirmed using an a PBC profile ELISA based on a mixture of the triple MIT3 hybroid and PBC-specific ANA gp210 and sp100 peptides (Quanta Lite PBC profile, INOVA Diagnostics, San Diego, California, USA). Serum samples were negative for $\mathrm{PBC}$-specific ANA by IIF. At the time of the diagnosis, both parents were alive and in good health, and no autoimmune diseases were reported in first grade relatives. Sera from the parents, maternal and paternal grandparents and one maternal uncle were also collected and tested for the presence of autoantibodies. The child's mother was found to be positive for AMA directed against the major PBC-specific

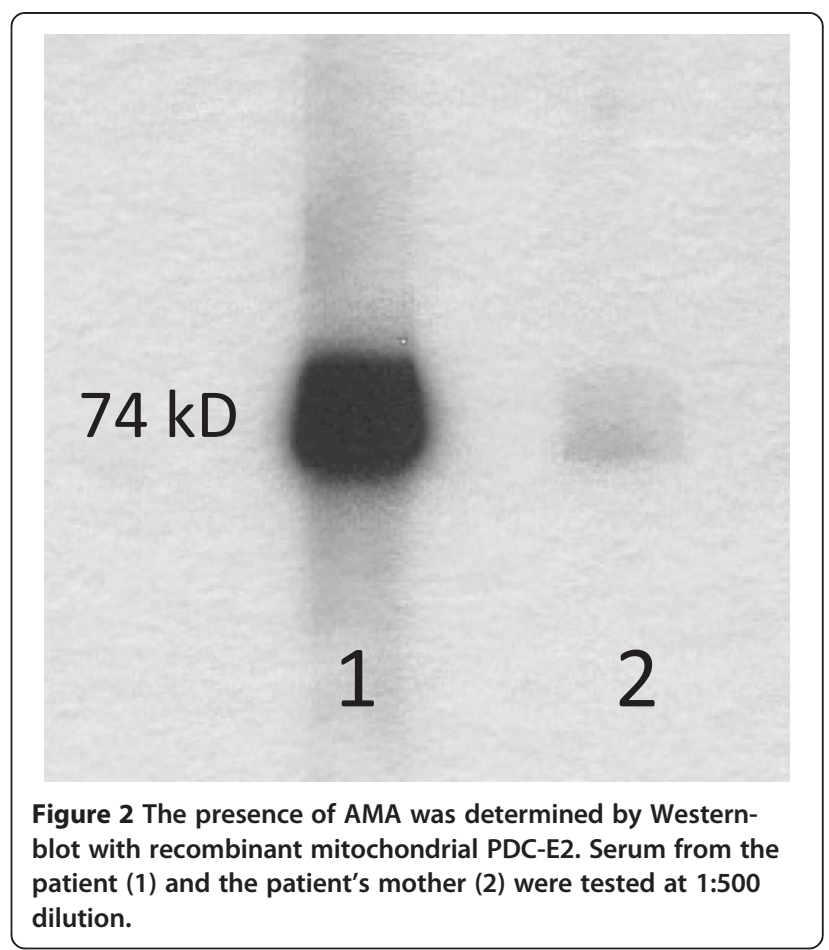

mitochondrial autoantigen, but had no symptoms or signs of liver disease (Figure 2).

A percutaneous liver biopsy was performed 4 weeks after presentation, when the INR normalized. Ductular structures were stained using cytokeratin 7 (CK-7) (NeoMarkers, Freemont, USA, working dilution 1:200), a marker selectively expressed by the biliary epithelial cells in the human liver. Histological examination showed a normal liver architecture with mild mixed inflammatory infiltrate and minimal portal fibrosis. Immunohistochemical staining for CK-7 demonstrated marked proliferation of medium and small sized bile ducts in portal and periportal areas. Focal hepatocytes demonstrated biliary metaplasia which was evident by the same immunohistochemical staining. Mixed steatosis was observed in about $20 \%$ of liver cells (Figure ss 3 ). Portal tracts were
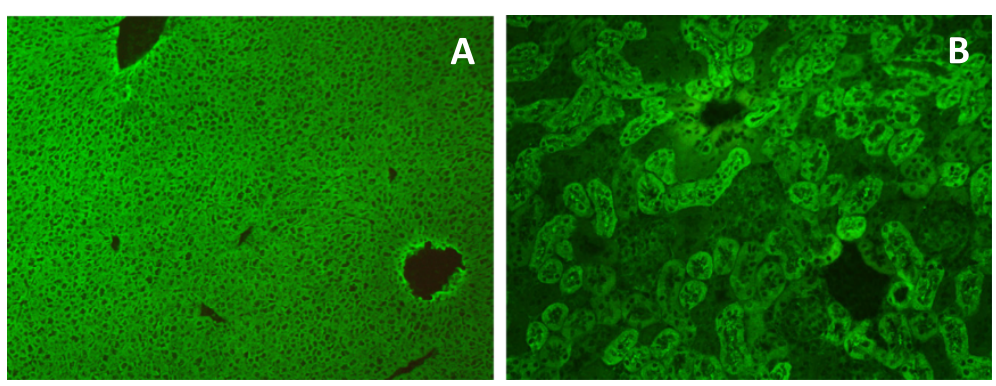

Figure 1 Autoantibody testing by conventional indirect immunofluorescence of the serum of the child on rat liver and kidney sections showing a typical staining of the liver cytoplasm (A) and renal tubules (B) corresponding to that seen by liver kidney microsomal type 1 autoantibodies. 

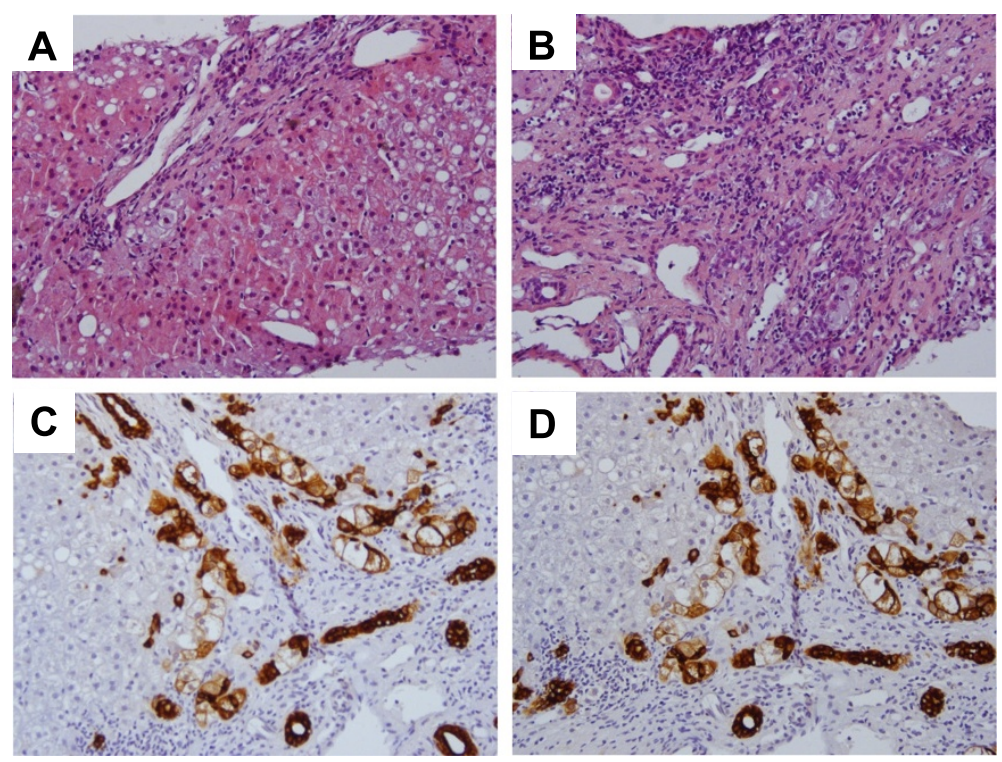

Figure 3 Representative analysis of liver tissue sections. Portal and periportal cellular inflammation: lymphocytes, monocytes/ macrophages and plasma cells infiltrate the portal tracts and invade the surrounding parenchyma, resulting in the characteristic picture of interface hepatitis. (A) Enlarged portal tracts fields with fibrosis and marked bile ductular proliferation, severe inflammatory biliary tract damage; liver cells showing moderate microvescicular steatosis (H\&E, 20X); (B) high-power view of an expanded portal tract field with moderate mixed inflammatory infiltrate and some features of flogistic bile duct damage (H\&E, 40X). (C and D) Immunohistology for biliary type cytokeratin 7 shows marked ductular proliferation in portal tracts fields and biliary metaplasia (abnormal positivity to cytokeratin 7 ) of peri-portal hepatocytes $(40 \mathrm{X})$.

expanded, fibrotic and oedematous, with a moderate inflammatory infiltrate, mainly represented by lymphocytes with spill-over features and isolated granulocytes. Interlobular bile ducts were affected by destructive lesions with focal destruction of basal membrane by inflammatory cells, occasionally migrating within the biliary epithelium. Typical histological lesions of $\mathrm{PBC}$ are difficult to be seen in the context of concomitant features of acute severe hepatitis related to AIH. It is possible that the first cycle of corticosteroid therapy had a stronger effect in ameliorating the hepatitis component, thereby allowing the cholangiopatic component (which is less likely to be responsive to corticosteroid therapy) to become more evident once the subacute lesions disappeared.

Five years after the acute episode, the child is on a low dose of steroid (prednisone $5 \mathrm{mg} /$ day) and azathioprine (50 mg/day), with normal liver function. AMA and antiLKM-1 remained positive for four years; in the course of the 5th follow up year, AMA became undetectable while anti-LKM-1 remained positive (January 2011).

\section{Discussion}

We herein present the rare finding of type $2 \mathrm{AIH}$ with the unexpected presence of AMA. Unlike other autoimmune liver diseases, typical features of $\mathrm{PBC}$ have never been reported in early childhood. Reported paediatric autoimmune liver disorders include AIH types 1 and 2, and autoimmune sclerosing cholangitis (ASC) [17]. The diagnosis of ASC relies on cholangiographic imaging changes. AIH type 2 is less frequent than AIH-1, affects mainly children and young adults and has a more aggressive course, leading to fulminant hepatic failure more often than type $1 \mathrm{AIH}$. In general, AIH responds satisfactorily to immunosuppressive treatment, with AIH-2 usually requiring treatment for life. The positive response to immunosuppression of the present case, in addition to the high titer of anti-LKM-1 antibodies, strongly supports the AIH component of the disease. Anti-LKM-1 antibodies in AIH-2 are specifically directed against cytochrome P4502D6. In addition to $\mathrm{AIH}-2$, antiLKM-1 is present in a minor proportion of chronic $\mathrm{HCV}$-infected patients. HCV infection was ruled out in the present case of AIH-2. A diagnosis compatible with $\mathrm{PBC}$ has been considered on the basis of the presence of PBC-specific AMA, evidence of cholestasis and histological lesions - not typical of PBC such as the granulomatous destruction of septal or interlobular bile ducts, but indicative of portal tract inflammation and ductular damage [13].

The presence of $\mathrm{PBC}$-specific AMA in this case is intriguing. AMA are highly specific for $\mathrm{PBC}$, and often precede the development of liver damage by several years, even in individuals who are asymptomatic and do 
not have any other evidence of chronic liver disease [13]. Although the mechanisms leading to the generation of AMA are unknown, it has been postulated that xenobiotic-induced and/or oxidative modification of mitochondrial autoantigens is a critical step leading to loss of immunological tolerance.

\section{Paediatric PBC}

Another intriguing finding of the present case is that PBC-specific AMA was present in conjunction with evidence of biliary epithelial cell destruction, diagnosed at the age of 3. The presence of AMA in the present case raises the question as to whether $\mathrm{PBC}$ has been reported among paediatric patients. The youngest child previously described with $\mathrm{PBC}$ was a six year old female [35] (Table 2). The remaining cases of 'paediatric' $\mathrm{PBC}$ have been described in adolescents [1,2]. Dahlan and colleagues reported two females aged 11 and 16 years, with confirmed $\mathrm{PBC}$ [2]. The first patient presented at 11 years of age with abdominal pain and raised aspartate aminotransferase (AST) $(48 \mathrm{U} / \mathrm{L}$; normal values $<35 \mathrm{U} / \mathrm{L})$, but all other liver biochemistry tests (including ALP) were normal ( $\gamma$ GT was not tested) [2]. Her abdominal pain continued and liver function tests demonstrated a raised $\gamma$ GT (107 U/L) at the age of 15, when she was found to be positive for AMA by IIF (1:800), although the specificity of the AMA was not stated [2]. No other autoantibodies were detected [2]. Her serum IgG and IgA were normal but IgM was raised [2]. A liver biopsy at age 16 showed stage II PBC (damaged segmental bile ducts with portal and periportal lymphoid infiltrates), and liver function tests at age 18 demonstrated a cholestatic profile with raised ALP $(660 \mathrm{U} / \mathrm{L})$ and slight increase of total bilirubin $(24 \mu \mathrm{mol} / \mathrm{L})$ [2]. It was at this phase that she developed symptoms of pruritus, fatigue and weight loss [2]. She was transplanted at age 21 following worsening of symptoms and increasingly abnormal liver biochemistry despite ursodeoxycholic acid (UDCA) treatment [2]. Histology of the explanted liver demonstrated stage IV PBC. An intriguing aspect of that case is her strong family history of liver disease, as the mother presented at the age of 30 with overlapping features of $\mathrm{PBC}$ and $\mathrm{AIH}$, and received a liver transplantation at the age of 34 [2]. Additionally, the grandmother and great-grandmother on the maternal side died of liver cirrhosis of unknown origin [2]. This is of interest given that the mother of the child in the current report is also AMA positive, suggesting a possible genetic predisposition. In the second case, a 16 year old female presented with Raynaud's and Sicca syndromes as well as raised AST (163 U/L), and was found to be positive for AMA (1:160). She was also positive for ANA (1:320) but it is not clear whether these ANA were those specific for PBC. (i.e. with a multiple nuclear dot or a rim like membranous pattern) [2]. Serum IgG and IgA were normal, but IgM was raised [2]. Histology confirmed stage II PBC at the age of 17 years, and she was started on UDCA ( $2 \mathrm{~g} /$ day), with improvement of her symptoms and liver biochemical tests [2].

\section{Paediatric 'PBC' due to genetic deficiences: The case of IPEX and IL-2}

Immunological and histological features of $\mathrm{PBC}$ have been reported in younger children, but these extreme

Table 2 Characteristics of paediatric patients with antimitochondrial antibody (AMA) positivity in primary biliary cirrhosis (PBC) and other liver or non-liver related diseases

\begin{tabular}{|c|c|c|c|c|c|}
\hline Reference & Age & Sex & Pathology & $\begin{array}{l}\text { Antibodies } \\
\text { Detected }\end{array}$ & Histology \\
\hline \multirow[t]{2}{*}{ Zamfir et al. } & 6 yrs & $M$ & ITP & AMA, ANA & - \\
\hline & 15 yrs & $M$ & $\mathrm{AHA}$ & AMA, ANA & - \\
\hline Gregorio et al. & 12 yrs & $\mathrm{F}$ & $\mathrm{AlH}$ & $\mathrm{AMA}$ & $\begin{array}{l}\text { Portoseptal mononuclear cell infiltration and extensive interface hepatitis, with } \\
\text { lymphocytic periportal necrosis. Consistent with chronic hepatitis. }\end{array}$ \\
\hline \multirow[t]{2}{*}{ Hannam et al. } & Birth & $\mathrm{F}$ & $\mathrm{NNH}$ & AMA & \\
\hline & Birth & $M$ & $\mathrm{NNH}$ & AMA & $\begin{array}{l}\text { Cholestasis, hepatitis, mild cholangiolitic changes and multi-nucleated giant } \\
\text { hepatocytes. Mild portal fibrosis. }\end{array}$ \\
\hline Aoki et al. & 6 months & $M$ & $\begin{array}{l}\text { IL-2Ra } \\
\text { deficiency }\end{array}$ & AMA & $\begin{array}{l}\text { Intense mononuclear lymphocyte infiltration of the portal tracts with preservation } \\
\text { of the lobular architecture. }\end{array}$ \\
\hline Tsuda et al. & 11 yrs & $M$ & IPEX & AMA & - \\
\hline Melegh et al. & $6 \mathrm{yrs}$ & $\mathrm{F}$ & $\mathrm{PBC}$ & $\mathrm{AMA}$ & $\begin{array}{l}\text { At } 6 \text { years: Fibrotic degeneration of the portal tracts, loss of bile ducts, ductal } \\
\text { proliferation, periportal hepatocytes separated by mononuclear inflammatory cells. }\end{array}$ \\
\hline \multirow[t]{2}{*}{ Dahlan et al. } & 11 yrs & $\mathrm{F}$ & $\mathrm{PBC}$ & AMA & At 16 years: Stage II PBCAt 21 years: Stage IV PBC (explanted liver) \\
\hline & 15 yrs & $\mathrm{F}$ & PBC & AMA, ANA & At 17 years: Stage II PBC \\
\hline
\end{tabular}


cases occur due to underlying genetic deficiencies such as IPEX syndrome or IL-2 receptor alpha (IL-2R $\alpha$ ) deficiency $[37,143]$. IPEX syndrome is a congenital disorder of immune regulation caused by mutations in the FOXP3 gene, which is required for the suppressive function of naturally arising CD4 + CD25 + regulatory T cells [143-145]. Tsuda et al. [37] note that patients with IPEX syndrome produce a variety of autoantibodies including AMA. Mutations in the FOXP3 gene (located on the centromeric region of the $\mathrm{X}$ chromosome) lead to decreased CD4 + CD25+ Tregs [63,64,146], and therefore failure to suppress the production of autoreactive $\mathrm{T}$ cells and multi-organ autoimmunity [37]. Tsuda and colleagues note that one individual in their study, an 11 year old male with IPEX, was positive for AMA, with no clinical or biochemical evidence of liver disease [37]. The AMA in that case was of the IgA isotype, with no AMA of the IgG isotype identified, and the plasma IgM and IgA levels were also raised [37]. It was not stated whether the AMA in that case was directed against PDC-E2, and it is unknown whether the child in that case eventually went on to develop PBC [37]. Aoki et al. [143] report the case of a male child born to consanguineous parents, who initially presented with recurrent infections at six months of age. At five years of age, liver biochemistry showed an elevated GGT, and a liver biopsy demonstrated mononuclear lymphocyte infiltration of the portal tracts [143]. These findings differ from the typical histological appearance of PBC, which includes non-suppurative cholangitis, ductopaenia, and sporadically non-caseating granuloma formation. The infant also had CD3+ CD25+ lymphocytopaenia leading to an abnormal $\mathrm{CD} 4: \mathrm{CD} 8$ ratio [143]. Infectious causes were ruled out, but antibody testing was positive for AMA, with reactivity to PDC-E2. Immunoblotting of peripheral lymphocytes showed the absence of the IL-2R $\alpha$. A thymic biopsy showed absent CD1a and increased Bcl-2 (an anti-apoptotic protein) expression, due to a four point mutation in FOXP3 leading to translational frameshift, which is similar to IPEX syndrome [143]. The authors suggested that the lack of CD4+CD25+ Tregs led to a proliferation of autoreactive $\mathrm{T}$ cells which were not induced to apoptose due to an increased Bcl-2 [143]. In turn, these autoreactive $\mathrm{T}$ cells contributed to the development of PBC (or PBC-like pathology), likely via close interaction with B cells $[143,144]$. The child in this case underwent myeloablative chemotherapy and allogenic stem cell transplantation, with complete resolution of his symptoms and no residual serological reactivity to recombinant PDC-E2 [143]. As mentioned, these cases do not represent true paediatric $\mathrm{PBC}$, as the underlying pathological process was linked to a genetic deficiency.

\section{Antimitochondrial antibodies in liver disease-free paediatric cases}

The presence of AMA is highly suggestive of $\mathrm{PBC}$, or predicts progression of an asymptomatic patient to overt PBC $[13,36]$. However, Zamfir et al. [83] noted the presence of AMA in 10 of 900 patients presenting with extrahepatic disorders. Of those patients, nine were presenting with haematological disease and one with a dermatological condition [83]. Eight of the ten had high AMA titres, with the remaining two having low titres, but the presence of AMA was confirmed by immunoblot. The immunodominant antigen in all positive AMA cases confirmed by immunoblot was PDC-E2 [83]. It is not known if there was also reactivity to other $\mathrm{PBC}$ specific AMA antigens such as the E2 subunits of branched chain oxoacid dehydrogenase complex (BCOADC-E2) and oxoglutarate complex (OGDC-E2) [13,26]. Interestingly three of the 10 patients were under the age of 20 , at 19, 15 and 6 years of age [83]. All three of these individuals were male, and had significant AMA titres, as well as positive ANA of unknown specificity [83]. The presenting disorders among the three were haematological, autoimmune haemolytic anaemia, thrombocytopaenia and idiopathic thrombocytopaenic purpura, respectively [83]. It should be noted that in the case of the 15 year old, the AMA appearance by IIF were atypical (non-anti-M2), and the positivity was not confirmed by immunoblot. It is therefore reasonable to speculate that this case may represent a non-PBC related AMA or a false positive AMA test. The 19 and 6 year old cases had AMA titers of greater than 1/640, and the presence of AMA was confirmed by immunoblotting [83]. These patients were unusual not only due to their young age, but also because they were male. Of the remaining 7 AMA positive patients with extrahepatic disorders, six were female [83]. It has been suggested that these patients may eventually go on to develop $\mathrm{PBC}$, but whether this occurred or not is unknown, as no liver biopsy or follow-up studies were performed.

\section{Antimitochondrial antibodies in cases with non-PBC related liver disease}

Unlike the above study where no liver disease was reported in the presence of high AMA titres, Gregorio et al. [26] report a 12 year old girl with autoimmune hepatitis type 1 who was AMA anti-M2 positive. This patient initially presented with a four month history of jaundice, fatigue, anorexia and weight loss, and on examination was found to have hepatosplenomegaly and liver disease stigmata [26]. Her serum bilirubin and ALT were elevated, but all other liver biochemistry was normal. She had increased IgG and was positive for PBCspecific anti-M2 AMA (titre 1/640) [26]. The presence of anti-M2 AMA was confirmed by western blot analysis 
[26]. Immunological testing for ANA, anti-smooth muscle antibody, and anti-LKM-1 were negative [26]. Histological assessment of six liver biopsies taken over several years showed chronic hepatitis with varying degrees of inflammation, but no evidence of PBC [26]. Treatment with prednisolone and azathioprine improved her condition, and her transaminases normalised, but she had three episodes of spontaneous bacterial peritonitis and four episodes of relapse due to poor treatment compliance [26]. Twelve years after her initial diagnosis, she developed liver failure and died following an intraperitoneal haemorrhage. Liver tissue obtained at autopsy confirmed cirrhosis with persistent inflammation, but no features confirmatory of or compatible with PBC [26]. Over the twelve years since diagnosis, she remained AMA positive, with titers ranging from $1 / 40$ to $1 / 1280$. She did not develop Sicca syndrome, systemic sclerosis or any other rheumatological condition associated with AMA positivity or PBC [26]. Her low IgM and ALP, as well as the lack of histological PBC features, are atypical for "overlap" between autoimmune hepatitis and $\mathrm{PBC}$ seen in adults $[13,26,142]$.

Transplacental passage of AMA and neonatal liver disease Hannam et al. [28] report two cases of neonatal liver disease, in which the transplacental passage of AMA occurred. The first case was that of a female infant born to a 32 year old mother with a three year history of pruritus and joint pain, who was AMA positive with normal liver function tests. The foetus was found to be hydropic, and required three intrauterine transfusions before delivery at 31 weeks by caesarean section [28]. The infant displayed deranged liver function tests, and was positive for AMA (titre 1/160) and ANA (1/20) [28]. These autoantibodies were present in the mother at the same titre, and both had the same antibody epitope recognition pattern to PDC-E2 and PDC-E3 binding protein (also known as PDC-X), recognising the major epitopic regions on these antigens [28]. Over several weeks the infant's condition and liver function tests improved, and the autoantibodies became undetectable. The second case involved a male infant born to a 28 year old mother following an uneventful pregnancy. The infant presented at five weeks with poor weight gain, jaundice, pale stools and an erythematous rash [28]. Liver function tests were deranged, and an antibody screen was positive for AMA (titre 1/20) and ANA (1/10) [28]. The mother was also positive for the same antibodies at the same titre, but she was asymptomatic and had normal liver biochemistry [28]. Titres of $1 / 10$ and $1 / 20$ based on IIF using liver, kidney, stomach tissues are considered significant in children, though in adults titers are considered positive if they exceed $1 / 40$. Antibodies in both mother and child had an identical epitope recognition pattern to PDC-E2 and PDC-E3 binding protein [28]. A liver biopsy of the infant demonstrated cholestasis with hepatitis and mild portal fibrosis [28]. Over the course of three months the infant's condition improved, liver biochemistry normalised, and the antibodies became undetectable [28]. In both cases the AMA were demonstrated to be maternal in origin, as in both infants they were of the placenta-crossing IgG1 and IgG 3 class, their concentrations declining over several weeks [28]. The epitope recognition pattern was also the same in both infant-mother pairs [28]. These cases are of interest given the transplacental passage of AMA, and its association with liver disease in the infants. Additionally, the AMA positivity was transient, akin to the current case report.

\section{Transient AMA positivity in acute liver failure}

In the patient herein illustrated, AMA became undetectable five years after the initial presentation. The decline of AMA over time may be due to the effect of immunosuppressive treatment or may indeed reveal the transient nature of the AMA positivity. A transient appearance of AMA has been previously noted in North American patients with acute liver failure (ALF). AMA have been reported to be present in up to $40 \%$ of adult patients with ALF and no other signs of PBC [32]. One study examined 217 serum samples from 69 patients with ALF, with samples collected over a 24-month period [32]. Details as to how many patients were children were not given. Initial testing showed that $40.6 \%$ of these patients had AMA, with reactivity against the major mitochondrial antigens (PDC-E2, BCOADC-E2, and OGDC-E2) [32]. By 24 months, only one subject remained positive for AMA directed against OGDC-E2 [32]. Similar data have been reported in the series of ALF patients from King's College Hospital in London [24]. In that report, 13/47 (28\%) sera from ALF patients tested positive for AMA, using the highly sensitive and specific MIT-3 (mitochondrial antigen 3) enzyme-linked immunosorbent assay (ELISA) [24]. Of interest, these 13 cases tested negative for AMA using IIF, indicating that the sensitivity for the detection of AMA largely depends on the methodology used [24].

Unlike the reported cases of transient AMA, liver histology in this case showed biliary damage. In our experience, ALF in paediatric patients is not associated with the presence of AMA. During a large-scale autoimmune-screening program over a 7-year period, only 2 out of 3808 Italian children with liver diseases of a variety of causes tested positive for AMA.

In conclusion, we report a case of AIH-2 with PBCspecific AMA positivity, documented both by IIF and mitochondrial antigen-specific immunoassays. Investigation of this peculiar case may give insight into the 
mechanisms responsible for the breakdown of immunological tolerance.

\section{Consent}

Written informed consent was obtained from the patient's parents for publication of this Case report and any accompanying images. A copy of the written consent is available for review by the Series Editor of this journal.

\section{Abbreviations}

AlH: Autoimmune Hepatitis; ALF: Acute Liver Failure; AMA: Antimitochondrial Antibodies; anti-LKM-1: Anti-liver Kidney Microsome type 1 antibodies; AST: Aspartate amonitransferase; GGT: Gamma Glutamyl Transpeptidase activity; IIF: Indirect Immunofluorescence; OLT: Orthotopic liver transplant; PBC: Primary Biliary Cirrhosis; PDC-E2: E2 subunit of the pyruvate dehydrogenase complex.

\section{Competing interest}

The author(s) declare that they have no competing interests'.

\section{Author details}

${ }^{1}$ Center for Autoimmune Liver Diseases, Humanitas Clinical and Research Center, Via Manzoni 56, 20089 Rozzano(MI), Italy. ²Division of Rheumatology, Allergy and Clinical Immunology, University of California at Davis, Davis, CA, USA. ${ }^{3}$ Clinical Laboratory, Ospedali Riuniti, Bergamo, Italy. ${ }^{4}$ Institute of Liver Studies, King's College London School of Medicine at King's College Hospital, Denmark Hill Campus, London, UK. ${ }^{5}$ Department of Medicine and Transplantation, Ospedali Riuniti, Bergamo, Italy. ${ }^{6}$ Department of Surgical and Gastroenterological Sciences, University of Padova, Padova, Italy. ${ }^{7}$ Center for Liver Research (CeLiveR), Ospedali Riuniti, Bergamo, Italy. ${ }^{8}$ Division of Pediatrics, Ospedali Riuniti, Bergamo, Italy. ${ }^{9}$ Department of Pediatrics, Federico II University, Naples, Italy.

Grant support: DSS is supported by Liver Immunodiagnostics, KCL grant; AL is supported by AISF (Associazione Italiana per lo Studio del Fegato), Mario Coppo award; DPB is supported by a CSL award from the Higher Education Funding Council for England.

\section{Authors contributions}

PI designed the study and had the overall supervision; PI, AL, DSS and DPB have written the first and subsequent drafts of the manuscript; PI, MGA, LF, GT conceived of the study, and participated in its design and coordination and helped to draft the manuscript. MGA, AL and DPB have carried out the immunoassays; MGA, MB, MC, RI, GT recruited biological material, collected data, and revised the manuscript. AS has performed histopathological assessment, immunohistochemical analysis and produced the photo of the liver tissue sections. All authors read and approved the final manuscript.

Received: 23 January 2012 Accepted: 20 July 2012

Published: 20 July 2012

\section{References}

1. Floreani A, Ostuni PA, Ferrara F, Guido M: Primary biliary cirrhosis: when and why does the disease develop? Dig Liver Dis 2006, 38(4):272-275.

2. Dahlan Y, Smith L, Simmonds D, Jewell LD, Wanless I, Heathcote EJ, Bain VG: Pediatric-onset primary biliary cirrhosis. Gastroenterology 2003 125(5):1476-1479.

3. EASL Clinical Practice Guidelines: management of cholestatic liver diseases. J Hepatol 2009, 51(2):237-267.

4. Abu-Mouch S, Selmi C, Benson GD, Kenny TP, Invernizzi P, Zuin M, Podda M, Rossaro L, Gershwin ME: Geographic clusters of primary biliary cirrhosis. Clin Dev Immunol 2003, 10(2-4):127-131.

5. Coppel RL, Gershwin ME: Primary biliary cirrhosis: the molecule and the mimic. Immunol Rev 1995, 144:17-49.

6. Folci M, Meda F: Gershwin ME. Selmi C: Cutting-Edge Issues in Primary Biliary Cirrhosis. Clin Rev Allergy Immunol; 2011.

7. Gershwin ME, Mackay IR: Primary biliary cirrhosis: paradigm or paradox for autoimmunity. Gastroenterology 1991, 100(3):822-833.
8. Giorgini A, Selmi C, Invernizzi P, Podda M, Zuin M, Gershwin ME: Primary biliary cirrhosis: solving the enigma. Ann N Y Acad Sci 2005, 1051:185-193.

9. Hirschfield GM, Gershwin ME: Primary biliary cirrhosis: one disease with many faces. Isr Med Assoc J 2011, 13(1):55-59.

10. Ichiki Y, Shimoda S, Ishibashi H, Gershwin ME: Is primary biliary cirrhosis a model autoimmune disease? Autoimmun Rev 2004, 3(4):331-336.

11. Invernizzi $P$, Selmi C, Gershwin ME: Update on primary biliary cirrhosis. Dig Liver Dis 2010, 42(6):401-408.

12. James OF, Bhopal R, Howel D, Gray J, Burt AD, Metcalf JV: Primary biliary cirrhosis once rare, now common in the United Kingdom? Hepatology 1999, 30(2):390-394.

13. Kaplan MM, Gershwin ME: Primary biliary cirrhosis. N Engl J Med 2005, 353(12):1261-1273

14. Kita H, Nalbandian G, Keeffe EB, Coppel RL, Gershwin ME: Pathogenesis of primary biliary cirrhosis. Clin Liver Dis 2003, 7(4):821-839.

15. Lindor KD, Gershwin ME, Poupon R, Kaplan M, Bergasa NV, Heathcote EJ: Primary biliary cirrhosis. Hepatology 2009, 50(1):291-308.

16. Lleo A, Invernizzi P, Gao B, Podda M, Gershwin ME: Definition of human autoimmunity-autoantibodies versus autoimmune disease. Autoimmun Rev 2010, 9(5):A259-A266.

17. Mieli-Vergani G, Vergani D: Autoimmune paediatric liver disease. World J Gastroenterol 2008, 14(21):3360-3367.

18. Nishio A, Keeffe EB, Ishibashi H, Gershwin EM: Diagnosis and treatment of primary biliary cirrhosis. Med Sci Monit 2000, 6(1):181-193.

19. Padgett KA, Lan RY, Leung PC, Lleo A, Dawson K, Pfeiff J, Mao TK, Coppe RL, Ansari AA, Gershwin ME: Primary biliary cirrhosis is associated with altered hepatic microRNA expression. J Autoimmun 2009, 32(3-4):246-253.

20. Selmi C, Balkwill DL, Invernizzi P, Ansari AA, Coppel RL, Podda M, Leung PS, Kenny TP, Van De Water J, Nantz MH, et al: Patients with primary biliary cirrhosis react against a ubiquitous xenobiotic-metabolizing bacterium. Hepatology 2003, 38(5):1250-1257.

21. Selmi C, Bowlus CL, Gershwin ME, Coppel RL: Primary biliary cirrhosis. Lancet 2011, 377(9777):1600-1609.

22. Tsuji K, Watanabe Y, Van De Water J, Nakanishi T, Kajiyama G, Parikh-Patel A, Coppel R, Gershwin ME: Familial primary biliary cirrhosis in Hiroshima. J Autoimmun 1999, 13(1):171-178.

23. Agmon-Levin N, Shapira Y, Selmi C, Barzilai O, Ram M, Szyper-Kravitz M, Sella S, Katz BS, Youinou P, Renaudineau Y, et al: A comprehensive evaluation of serum autoantibodies in primary biliary cirrhosis. J Autoimmun 2010, 34(1):55-58.

24. Bernal W, Meda F, Ma Y, Bogdanos DP, Vergani D: Disease-specific autoantibodies in patients with acute liver failure: the King's College London Experience. Hepatology 2008, 47(3):1096-1097. author reply 1097.

25. Bizzaro N, Covini G, Rosina F, Muratori P, Tonutti E, Villalta D, Pesente F, Alessio MG, Tampoia M, Antico A, et al: Overcoming a "Probable" Diagnosis in Antimitochondrial Antibody Negative Primary Biliary Cirrhosis: Study of 100 Sera and Review of the Literature. Clin Rev Allergy Immunol 2010, 42(3):288-297.

26. Bogdanos DP, Baum $H$, Vergani D: Antimitochondrial and other autoantibodies. Clin Liver Dis 2003, 7(4):759-777. vi.

27. Gregorio GV, Portmann B, Mowat AP, Vergani D, Mieli-Vergani G: A 12-yearold girl with antimitochondrial antibody-positive autoimmune hepatitis. J Hepatol 1997, 27(4):751-754.

28. Hannam S, Bogdanos DP, Davies ET, Hussain MJ, Portmann BC, Mieli-Vergani $G$, Vergani D: Neonatal liver disease associated with placental transfer of anti-mitochondrial antibodies. Autoimmunity 2002, 35(8):545-550.

29. Iwayama T, Leung PS, Coppel RL, Roche TE, Patel MS, Mizushima Y, Nakagawa T, Dickson R, Gershwin ME: Specific reactivity of recombinant human PDC-E1 alpha in primary biliary cirrhosis. J Autoimmun 1991, 4(5):769-778.

30. Joplin R, Gershwin ME: Ductular expression of autoantigens in primary biliary cirrhosis. Semin Liver Dis 1997, 17(2):97-103.

31. Kita H, Matsumura S, He XS, Ansari AA, Lian ZX, Van de Water J, Coppel RL, Kaplan MM, Gershwin ME: Quantitative and functional analysis of PDC-E2specific autoreactive cytotoxic T lymphocytes in primary biliary cirrhosis. J Clin Invest 2002, 109(9):1231-1240.

32. Leung PS, Rossaro L, Davis PA, Park O, Tanaka A, Kikuchi K, Miyakawa H, Norman GL, Lee W, Gershwin ME: Antimitochondrial antibodies in acute liver failure: implications for primary biliary cirrhosis. Hepatology 2007, 46(5):1436-1442 
33. Mattalia A, Luttig B, Rosina F, Leung PS, Van de Water J, Bauducci M, Ciancio A, Boker KH, Worman H, Cooper RL, et al: Persistence of autoantibodies against recombinant mitochondrial and nuclear pore proteins after orthotopic liver transplantation for primary biliary cirrhosis. J Autoimmun 1997, 10(5):491-497.

34. Meda F, Zuin M, Invernizzi P, Vergani D, Selmi C: Serum autoantibodies: a road map for the clinical hepatologist. Autoimmunity 2008, 41(1):27-34.

35. Melegh B, Skuta G, Pajor L, Hegedus G, Sumegi B: Autoantibodies against subunits of pyruvate dehydrogenase and citrate synthase in a case of paediatric biliary cirrhosis. Gut 1998, 42(5):753-756.

36. Mitchison HC, Bassendine MF, Hendrick A, Bennett MK, Bird G, Watson AJ, James OF: Positive antimitochondrial antibody but normal alkaline phosphatase: is this primary biliary cirrhosis? Hepatology 1986, 6(6):1279-1284.

37. Tsuda M, Torgerson TR, Selmi C, Gambineri E, Carneiro-Sampaio M Mannurita SC, Leung PS, Norman GL, Gershwin ME: The spectrum of autoantibodies in IPEX syndrome is broad and includes antimitochondrial autoantibodies. J Autoimmun 2010, 35(3):265-268.

38. Wesierska-Gadek J, Penner E, Battezzati PM, Selmi C, Zuin M, Hitchman E, Worman HJ, Gershwin ME, Podda M, Invernizzi P: Correlation of initial autoantibody profile and clinical outcome in primary biliary cirrhosis. Hepatology 2006, 43(5):1135-1144.

39. Bogdanos DP, Komorowski L: Disease-specific autoantibodies in primary biliary cirrhosis. Clinica chimica acta; international journal of clinical chemistry 2011, 412(7-8):502-512

40. Miyakawa H, Tanaka A, Kikuchi K, Matsushita M, Kitazawa E, Kawaguchi N, Fujikawa H, Gershwin ME: Detection of antimitochondrial autoantibodies in immunofluorescent AMA-negative patients with primary biliary cirrhosis using recombinant autoantigens. Hepatology 2001, 34(2):243-248.

41. Oertelt $S$, Rieger $R$, Selmi C, Invernizzi P, Ansari AA, Coppel RL, Podda M, Leung PS, Gershwin ME: A sensitive bead assay for antimitochondrial antibodies: Chipping away at AMA-negative primary biliary cirrhosis. Hepatology 2007, 45(3):659-665

42. Harada K, Sudo Y, Kono N, Ozaki S, Tsuneyama K, Gershwin ME, Nakanuma $Y$ : In situ nucleic acid detection of PDC-E2, BCOADC-E2, OGDC-E2, PDCE1alpha, BCOADC-E1alpha, OGDC-E1, and the E3 binding protein (protein X) in primary biliary cirrhosis. Hepatology 1999, 30(1):36-45.

43. Leung PS, Cha S, Joplin RE, Galperin C, Van de Water J, Ansari AA, Coppel RL, Schatz PJ, Cwirla S, Fabris LE, et al: Inhibition of PDC-E2 human combinatorial autoantibodies by peptide mimotopes. J Autoimmun 1996, 9(6):785-793.

44. Leung PS, Chuang DT, Wynn RM, Cha S, Danner DJ, Ansari A, Coppel RL, Gershwin ME: Autoantibodies to BCOADC-E2 in patients with primary biliary cirrhosis recognize a conformational epitope. Hepatology 1995, 22(2):505-513.

45. Liu H, Norman GL, Shums Z, Worman HJ, Krawitt EL, Bizzaro N, Vergani D, Bogdanos DP, Dalekos GN, Milkiewicz P, et al: PBC screen: an lgG/lgA dual isotype ELISA detecting multiple mitochondrial and nuclear autoantibodies specific for primary biliary cirrhosis. J Autoimmun 2010, 35(4):436-442

46. Nishio A, Van de Water J, Leung PS, Joplin R, Neuberger JM, Lake J, Bjorkland A, Totterman TH, Peters M, Worman HJ, et al: Comparative studies of antimitochondrial autoantibodies in sera and bile in primary biliary cirrhosis. Hepatology 1997, 25(5):1085-1089.

47. Olafsson S, Gudjonsson H, Selmi C, Amano K, Invernizzi P, Podda M, Gershwin ME: Antimitochondrial antibodies and reactivity to N. aromaticivorans proteins in Icelandic patients with primary biliary cirrhosis and their relatives. Am J Gastroenterol 2004, 99(11):2143-2146.

48. Vergani D, Alvarez F, Bianchi FB, Cancado EL, Mackay IR, Manns MP, Nishioka $M$, Penner E: Liver autoimmune serology: a consensus statement from the committee for autoimmune serology of the International Autoimmune Hepatitis Group. J Hepatol 2004, 41(4):677-683.

49. Mytilinaiou MG, Bogdanos DP: Primary biliary cirrhosis-specific autoantibodies in patients with systemic sclerosis. Dig Liver Dis 2009 41(12):916-917. author reply 916-917.

50. Dahnrich C, Pares A, Caballeria L, Rosemann A, Schlumberger W, Probst C, Mytilinaiou M, Bogdanos D, Vergani D, Stocker W, et al: New ELISA for detecting primary biliary cirrhosis-specific antimitochondrial antibodies. Clin Chem 2009, 55(5):978-985.
51. Rieger $R$, Gershwin ME: The $X$ and why of xenobiotics in primary biliary cirrhosis. J Autoimmun 2007, 28(2-3):76-84.

52. Amano K, Leung PS, Xu Q, Marik J, Quan C, Kurth MJ, Nantz MH, Ansari AA, Lam KS, Zeniya $M$, et al: Xenobiotic-induced loss of tolerance in rabbits to the mitochondrial autoantigen of primary biliary cirrhosis is reversible. $\mathrm{J}$ Immunol 2004, 172(10):6444-6452.

53. Ishibashi H, Nakamura M, Shimoda S, Gershwin ME: T cell immunity and primary biliary cirrhosis. Autoimmun Rev 2003, 2(1):19-24.

54. Lan RY, Salunga TL, Tsuneyama K, Lian ZX, Yang GX, Hsu W, Moritoki Y, Ansari AA, Kemper C, Price J, et al: Hepatic IL-17 responses in human and murine primary biliary cirrhosis. J Autoimmun 2009, 32(1):43-51.

55. Lan RY, Selmi C, Gershwin ME: The regulatory, inflammatory, and T cell programming roles of interleukin-2 (IL-2). J Autoimmun 2008, 31(1):7-12.

56. Leung PS, Van de Water J, Coppel RL, Nakanuma Y, Munoz S, Gershwin ME: Molecular aspects and the pathological basis of primary biliary cirrhosis J Autoimmun 1996, 9(2):119-128.

57. Lleo A, Bowlus CL, Yang GX, Invernizzi P, Podda M, Van de Water J, Ansari AA, Coppel RL, Worman HJ, Gores GJ, et al: Biliary apotopes and antimitochondrial antibodies activate innate immune responses in primary biliary cirrhosis. Hepatology 2010, 52(3):987-998.

58. Lleo A, Invernizzi P, Mackay IR, Prince H, Zhong RQ, Gershwin ME: Etiopathogenesis of primary biliary cirrhosis. World J Gastroenterol 2008, 14(21):3328-3337.

59. Lleo A, Invernizzi P, Selmi C, Coppel RL, Alpini G, Podda M, Mackay IR, Gershwin ME: Autophagy: highlighting a novel player in the autoimmunity scenario. J Autoimmun 2007, 29(2-3):61-68.

60. Lleo A, Selmi C, Invernizzi P, Podda M, Coppel RL, Mackay IR, Gores GJ, Ansari AA, Van de Water J, Gershwin ME: Apotopes and the biliary specificity of primary biliary cirrhosis. Hepatology 2009, 49(3):871-879.

61. Lleo A, Selmi C, Invernizzi P, Podda M, Gershwin ME: The consequences of apoptosis in autoimmunity. J Autoimmun 2008, 31(3):257-262.

62. Lleo A, Shimoda S, Ishibashi H, Gershwin ME: Primary biliary cirrhosis and autoimmune hepatitis: apotopes and epitopes. J Gastroenterol 2011, 46(Suppl 1):29-38.

63. Longhi MS, Hussain MJ, Bogdanos DP, Quaglia A, Mieli-Vergani G, Ma Y, Vergani D: Cytochrome P450IID6-specific CD8 T cell immune responses mirror disease activity in autoimmune hepatitis type 2. Hepatology 2007 46(2):472-484.

64. Longhi MS, Ma Y, Mitry RR, Bogdanos DP, Heneghan M, Cheeseman P, Mieli-Vergani G, Vergani D: Effect of CD4+ CD25+ regulatory T-cells on CD8 T-cell function in patients with autoimmune hepatitis. $J$ Autoimmun 2005, 25(1):63-71.

65. Naiki M, Yoshida SH, Ansari AA, Bill J, Gershwin ME: Activation of autoreactive T-cell clones from NZB.H-2bm12 mice. J Autoimmun 1994, 7(3):275-290.

66. Rong G, Zhong R, Lleo A, Leung PS, Bowlus CL, Yang GX, Yang CY, Coppel RL, Ansari AA, Cuebas DA, et al: Epithelial cell specificity and apotope recognition by serum autoantibodies in primary biliary cirrhosis. Hepatology 2011, 54(1):196-203

67. Salunga TL, Cui ZG, Shimoda S, Zheng HC, Nomoto K, Kondo T, Takano Y, Selmi C, Alpini G, Gershwin ME, et al: Oxidative stress-induced apoptosis of bile duct cells in primary biliary cirrhosis. J Autoimmun 2007 , 29(2-3):78-86

68. Sasaki M, Ansari A, Pumford N, van de Water J, Leung PS, Humphries KM, Szweda LI, Nakanuma Y, Roche TE, Coppel RL, et al: Comparative immunoreactivity of anti-trifluoroacetyl (TFA) antibody and anti-lipoic acid antibody in primary biliary cirrhosis: searching for a mimic. J Autoimmun 2000, 15(1):51-60.

69. Selmi C, Affronti A, Ferrari L, Invernizzi P: Immune-mediated bile duct injury: The case of primary biliary cirrhosis. World J Gastrointest Pathophysiol 2010, 1(4):118-128.

70. Selmi C, Invernizzi P, Tripputi P, Battezzati PM, Bignotto M, Zuin M, Crosignani A, Podda M: T-cell receptor polymorphism in primary biliary cirrhosis. Annali italiani di medicina interna: organo ufficiale della Societa italiana di medicina interna 2003, 18(3):149-153.

71. Selmi C, Mackay IR, Gershwin ME: The autoimmunity of primary biliary cirrhosis and the clonal selection theory. Immunol Cell Biol 2011, 89(1):70-80 
72. Selmi C, Ross SR, Ansari AA, Invernizzi P, Podda M, Coppel RL, Gershwin ME: Lack of immunological or molecular evidence for a role of mouse mammary tumor retrovirus in primary biliary cirrhosis. Gastroenterology 2004, 127(2):493-501.

73. Shimoda S, Harada K, Niiro H, Shirabe K, Taketomi A, Maehara Y, Tsuneyama K, Nakanuma Y, Leung P, Ansari AA, et al: Interaction between Toll-like receptors and natural killer cells in the destruction of bile ducts in primary biliary cirrhosis. Hepatology 2011, 53(4):1270-1281

74. Shimoda S, Ishikawa F, Kamihira T, Komori A, Niiro H, Baba E, Harada K, Isse $\mathrm{K}$, Nakanuma $\mathrm{Y}$, Ishibashi $\mathrm{H}$, et al: Autoreactive T-cell responses in primary biliary cirrhosis are proinflammatory whereas those of controls are regulatory. Gastroenterology 2006, 131(2):606-618.

75. Shimoda S, Miyakawa H, Nakamura M, Ishibashi H, Kikuchi K, Kita H, Niiro H, Arinobu $Y$, Ono N, Mackay IR, et al: CD4 T-cell autoreactivity to the mitochondrial autoantigen PDC-E2 in AMA-negative primary biliary cirrhosis. J Autoimmun 2008, 31(2):110-115.

76. Shoenfeld Y, Selmi C, Zimlichman E, Gershwin ME: The autoimmunologist: geoepidemiology, a new center of gravity, and prime time for autoimmunity. J Autoimmun 2008, 31(4):325-330.

77. Tanaka A, Leung PS, Kenny TP, Au-Young J, Prindiville T, Coppel RL, Ansari AA, Gershwin ME: Genomic analysis of differentially expressed genes in liver and biliary epithelial cells of patients with primary biliary cirrhosis. J Autoimmun 2001, 17(1):89-98.

78. Tanimoto H, Shimoda S, Nakamura M, Ishibashi H, Kawano A, Kamihira T, Matsushita S, Gershwin ME, Harada M: Promiscuous T cells selected by Escherichia coli: OGDC-E2 in primary biliary cirrhosis. J Autoimmun 2003, 20(3):255-263

79. Teuber SS, Coppel RL, Ansari AA, Leung PS, Neve R, Mackay IR, Gershwin ME: The identification and cloning of the murine genes encoding the liver specific F alloantigens. J Autoimmun 1991, 4(6):857-870.

80. Van de Water J, Shimoda S, Niho Y, Coppel R, Ansari A, Gershwin ME: The role of T cells in primary biliary cirrhosis. Semin Liver Dis 1997, 17(2):105-113

81. Wu CT, Eiserich JP, Ansari AA, Coppel RL, Balasubramanian S, Bowlus CL, Gershwin ME, Van De Water J: Myeloperoxidase-positive inflammatory cells participate in bile duct damage in primary biliary cirrhosis through nitric oxide-mediated reactions. Hepatology 2003 38(4):1018-1025.

82. Wu SJ, Yang YH, Tsuneyama K, Leung PS, Illarionov P, Gershwin ME, Chuang $\mathrm{YH}$ : Innate immunity and primary biliary cirrhosis: activated invariant natural killer T cells exacerbate murine autoimmune cholangitis and fibrosis. Hepatology 2011, 53(3):915-925.

83. Zamfir O, Briaud I, Dubel L, Ballot E, Johanet C: Anti-pyruvate dehydrogenase autoantibodies in extrahepatic disorders. J Hepatol 1999 31(5):964-965

84. Zhang W, Ono Y, Miyamura Y, Bowlus CL, Gershwin ME, Maverakis E: T cell clonal expansions detected in patients with primary biliary cirrhosis express CX3CR1. J Autoimmun 2011, 37(2):71-78.

85. Invernizzi P, Selmi C, Mackay IR, Podda M, Gershwin ME: From bases to basis: linking genetics to causation in primary biliary cirrhosis. Clin Gastroenterol Hepatol 2005, 3(5):401-410.

86. Bernuzzi F, Fenoglio D, Battaglia F, Fravega M, Gershwin ME, Indiveri F, Ansari AA, Podda M, Invernizzi P, Filaci G: Phenotypical and functional alterations of $\mathrm{CD} 8$ regulatory $\mathrm{T}$ cells in primary biliary cirrhosis. J Autoimmun 2010, 35(3):176-180.

87. Hirschfield GM, Invernizzi P: Progress in the genetics of primary biliary cirrhosis. Semin Liver Dis 2011, 31(2):147-156.

88. Invernizzi P: Future directions in genetic for autoimmune diseases J Autoimmun 2009, 33(1):1-2

89. Invernizzi P: HLA in primary biliary cirrhosis: An old story now reviving Hepatology 2011,

90. Invernizzi P, Battezzati PM, Crosignani A, Perego F, Poli F, Morabito A, De Arias AE, Scalamogna M, Zuin M, Podda M: Peculiar HLA polymorphisms in Italian patients with primary biliary cirrhosis. J Hepatol 2003, 38(4):401-406

91. Invernizzi P, Gershwin ME: The genetic basis of primary biliary cirrhosis: premises, not promises. Gastroenterology 2008, 135(4):1044-1047.

92. Invernizzi P, Gershwin ME: The genetics of human autoimmune disease. J Autoimmun 2009, 33(3-4):290-299.
93. Invernizzi P, Miozzo M, Battezzati PM, Bianchi I, Grati FR, Simoni G, Selmi C, Watnik M, Gershwin ME, Podda M: Frequency of monosomy $X$ in women with primary biliary cirrhosis. Lancet 2004, 363(9408):533-535.

94. Invernizzi P, Miozzo M, Oertelt-Prigione S, Meroni PL, Persani L, Selmi C, Battezzati PM, Zuin M, Lucchi S, Marasini B, et al: X monosomy in female systemic lupus erythematosus. Ann N Y Acad Sci 2007, 1110:84-91.

95. Invernizzi P, Miozzo M, Selmi C, Persani L, Battezzati PM, Zuin M, Lucchi S, Meroni PL, Marasini B, Zeni S, et al: X chromosome monosomy: a common mechanism for autoimmune diseases. J Immunol 2005, 175(1):575-578.

96. Invernizzi P, Pasini S, Selmi C, Gershwin ME, Podda M: Female predominance and $\mathrm{X}$ chromosome defects in autoimmune diseases. J Autoimmun 2009, 33(1):12-16.

97. Invernizzi P, Selmi C, Poli F, Frison S, Floreani A, Alvaro D, Almasio P, Rosina $F$, Marzioni M, Fabris L, et al: Human leukocyte antigen polymorphisms in Italian primary biliary cirrhosis: a multicenter study of 664 patients and 1992 healthy controls. Hepatology 2008, 48(6):1906-1912.

98. Kikuchi K, Lian ZX, Kimura Y, Selmi C, Yang GX, Gordon SC, Invernizzi P, Podda M, Coppel RL, Ansari AA, et al: Genetic polymorphisms of toll-like receptor 9 influence the immune response to $\mathrm{CpG}$ and contribute to hyper-IgM in primary biliary cirrhosis. J Autoimmun 2005, 24(4):347-352

99. Kimura Y, Selmi C, Leung PS, Mao TK, Schauer J, Watnik M, Kuriyama S, Nishioka M, Ansari AA, Coppel RL, et al: Genetic polymorphisms influencing xenobiotic metabolism and transport in patients with primary biliary cirrhosis. Hepatology 2005, 41(1):55-63.

100. Liu X, Invernizzi P, Lu Y, Kosoy R, Bianchi I, Podda M, Xu C, Xie G, Macciardi $F$, Selmi $C$, et al: Genome-wide meta-analyses identify three loci associated with primary biliary cirrhosis. Nat Genet 2010, 42(8):658-660

101. Miozzo M, Selmi C, Gentilin B, Grati FR, Sirchia S, Oertelt S, Zuin M, Gershwin ME, Podda M, Invernizzi P: Preferential X chromosome loss but random inactivation characterize primary biliary cirrhosis. Hepatology 2007 46(2):456-462

102. Mitchell MM, Lleo A, Zammataro L, Mayo MJ, Invernizzi P, Bach N, Shimoda S, Gordon S, Podda M, Gershwin ME, et al: Epigenetic investigation of variably $\mathrm{X}$ chromosome inactivated genes in monozygotic female twins discordant for primary biliary cirrhosis. Epigenetics 2011, 6(1):95-102.

103. Niro GA, Poli F, Andriulli A, Bianchi I, Bernuzzi F, Caliari L, Fontana R, Gioffreda D, Valvano MR, Podda M, et al: TNF-alpha polymorphisms in primary biliary cirrhosis: a northern and southern Italian experience. Ann N Y Acad Sci 2009, 1173:557-563.

104. Oertelt S, Selmi C, Invernizzi P, Podda M, Gershwin ME: Genes and goals: an approach to microarray analysis in autoimmunity. Autoimmun Rev 2005, 4(7):414-422.

105. Selmi C, Invernizzi P, Miozzo M, Podda M, Gershwin ME: Primary biliary cirrhosis: does X mark the spot? Autoimmun Rev 2004, 3(7-8):493-499.

106. Selmi C, Invernizzi P, Zuin M, Podda M, Gershwin ME: Genetics and geoepidemiology of primary biliary cirrhosis: following the footprints to disease etiology. Semin Liver Dis 2005, 25(3):265-280.

107. Selmi C, Invernizzi P, Zuin M, Podda M, Seldin MF, Gershwin ME: Genes and (auto)immunity in primary biliary cirrhosis. Genes Immun 2005, 6(7):543-556.

108. Selmi C, Mayo MJ, Bach N, Ishibashi H, Invernizzi P, Gish RG, Gordon SC, Wright $\mathrm{HI}$, Zweiban B, Podda M, et al: Primary biliary cirrhosis in monozygotic and dizygotic twins: genetics, epigenetics, and environment. Gastroenterology 2004, 127(2):485-492.

109. Selmi C, Meda F, Kasangian A, Invernizzi P, Tian Z, Lian Z, Podda M, Gershwin ME: Experimental evidence on the immunopathogenesis of primary biliary cirrhosis. Cell Mol Immunol 2010, 7(1):1-10.

110. Tanaka A, Invernizzi P, Ohira H, Kikuchi K, Nezu S, Kosoy R, Seldin MF, Gershwin ME, Takikawa H: Replicated association of 17q12-21 with susceptibility of primary biliary cirrhosis in a Japanese cohort. Tissue Antigens 2011, 78(1):65-68.

111. Tanaka A, Nezu S, Uegaki S, Kikuchi K, Shibuya A, Miyakawa H, Takahashi S, Bianchi I, Zermiani P, Podda M, et al: Vitamin D receptor polymorphisms are associated with increased susceptibility to primary biliary cirrhosis in Japanese and Italian populations. J Hepatol 2009, 50(6):1202-1209.

112. Kita $\mathrm{H}, \mathrm{He} X \mathrm{~S}$, Gershwin ME: Autoimmunity and environmental factors in the pathogenesis of primary biliary cirrhosis. Ann Med 2004, 36(1):72-80. 
113. Leung PS, Quan C, Park O, Van de Water J, Kurth MJ, Nantz MH, Ansari AA, Coppel RL, Lam KS, Gershwin ME: Immunization with a xenobiotic 6bromohexanoate bovine serum albumin conjugate induces antimitochondrial antibodies. J Immunol 2003, 170(10):5326-5332.

114. Selmi C, Gershwin ME: Bacteria and human autoimmunity: the case of primary biliary cirrhosis. Curr Opin Rheumatol 2004, 16(4):406-410.

115. Tanaka A, Prindiville TP, Gish R, Solnick JV, Coppel RL, Keeffe EB, Ansari A, Gershwin ME: Are infectious agents involved in primary biliary cirrhosis? A PCR approach. J Hepatol 1999, 31(4):664-671.

116. Van de Water J, Turchany J, Leung PS, Lake J, Munoz S, Surh CD, Coppel R, Ansari A, Nakanuma Y, Gershwin ME: Molecular mimicry in primary biliary cirrhosis. Evidence for biliary epithelial expression of a molecule crossreactive with pyruvate dehydrogenase complex-E2. J Clin Invest 1993, 91(6):2653-2664.

117. Smyk D, Cholongitas E, Kriese S, Rigopoulou El, Bogdanos DP: Primary biliary cirrhosis: family stories. Autoimmune Dis 2011, 2011:189585.

118. Smyk D, Mytilinaiou MG, Rigopoulou El, Bogdanos DP: PBC triggers in water reservoirs, coal mining areas and waste disposal sites: from Newcastle to New York. Dis Markers 2010, 29(6):337-344.

119. Smyk D, Rigopoulou El, Baum H, Burroughs AK, Vergani D, Bogdanos DP. Autoimmunity and Environment: Am I at risk? Clin Rev Allergy Immunol 2011, 42(2):199-212.

120. Bogdanos D, Pusl T, Rust C, Vergani D, Beuers U: Primary biliary cirrhosis following Lactobacillus vaccination for recurrent vaginitis. J Hepato/ 2008, 49(3):466-473.

121. Bogdanos DP, Baum H, Butler P, Rigopoulou El, Davies ET, Ma Y, Burroughs AK, Vergani D: Association between the primary biliary cirrhosis specific anti-sp100 antibodies and recurrent urinary tract infection. Dig Liver Dis 2003, 35(11):801-805

122. Bogdanos DP, Baum H, Grasso A, Okamoto M, Butler P, Ma Y, Rigopoulou E, Montalto P, Davies ET, Burroughs AK, et al: Microbial mimics are major targets of crossreactivity with human pyruvate dehydrogenase in primary biliary cirrhosis. J Hepatol 2004, 40(1):31-39.

123. Bogdanos DP, Baum H, Gunsar F, Arioli D, Polymeros D, Ma Y, Burroughs AK, Vergani D: Extensive homology between the major immunodominant mitochondrial antigen in primary biliary cirrhosis and Helicobacter pylori does not lead to immunological cross-reactivity. Scand J Gastroenterol 2004, 39(10):981-987.

124. Bogdanos DP, Baum H, Okamoto M, Montalto P, Sharma UC, Rigopoulou El, Vlachogiannakos J, Ma Y, Burroughs AK, Vergani D: Primary biliary cirrhosis is characterized by lgG3 antibodies cross-reactive with the major mitochondrial autoepitope and its Lactobacillus mimic. Hepatology 2005 42(2):458-465.

125. Bogdanos DP, Baum H, Sharma UC, Grasso A, Ma Y, Burroughs AK, Vergani $D$ : Antibodies against homologous microbial caseinolytic proteases $\mathrm{P}$ characterise primary biliary cirrhosis. J Hepatol 2002, 36(1):14-21.

126. Bogdanos DP, Baum H, Vergani D, Burroughs AK: The role of E. coli infection in the pathogenesis of primary biliary cirrhosis. Dis Markers 2010, 29(6):301-311.

127. Bogdanos DP, Koutsoumpas A, Baum H, Vergani D: Borrelia Burgdorferi: a new self-mimicking trigger in primary biliary cirrhosis. Dig Liver Dis 2006, 38(10):781-782. author reply 782-783.

128. Bogdanos DP, Pares A, Baum H, Caballeria L, Rigopoulou El, Ma Y, Burroughs AK, Rodes J, Vergani D: Disease-specific cross-reactivity between mimicking peptides of heat shock protein of Mycobacterium gordonae and dominant epitope of E2 subunit of pyruvate dehydrogenase is common in Spanish but not British patients with primary biliary cirrhosis. J Autoimmun 2004, 22(4):353-362.

129. Bogdanos DP, Vergani D: Origin of cross-reactive autoimmunity in primary biliary cirrhosis. Liver Int 2006, 26(6):633-635.

130. Bogdanos DP, Vergani D: Bacteria and primary biliary cirrhosis. Clin Rev Allergy Immunol 2009, 36(1):30-39.

131. Koutsoumpas A, Mytilinaiou M, Polymeros D, Dalekos GN, Bogdanos DP: Anti-Helicobacter pylori antibody responses specific for VacA do not trigger primary biliary cirrhosis-specific antimitochondrial antibodies. Eur J Gastroenterol Hepatol 2009, 21(10):1220.

132. Vergani $\mathrm{D}$, Bogdanos DP, Baum H: Unusual suspects in primary biliary cirrhosis. Hepatology 2004, 39(1):38-41.

133. Selmi C, De Santis M, Cavaciocchi F, Gershwin ME: Infectious agents and xenobiotics in the etiology of primary biliary cirrhosis. Dis Markers 2010, 29(6):287-299.
134. Selmi C, Gershwin ME: The role of environmental factors in primary biliary cirrhosis. Trends Immunol 2009, 30(8):415-420.

135. Selmi C, Cocchi CA, Zuin M, Gershwin ME: The chemical pathway to primary biliary cirrhosis. Clin Rev Allergy Immunol 2009, 36(1):23-29.

136. Invernizzi P: Geoepidemiology of autoimmune liver diseases. J Autoimmun 2010, 34(3):J300-J306.

137. Parikh-Patel A, Gold EB, Worman H, Krivy KE, Gershwin ME: Risk factors for primary biliary cirrhosis in a cohort of patients from the united states. Hepatology 2001, 33(1):16-21.

138. Corpechot C, Chretien Y, Chazouilleres O, Poupon R: Demographic, lifestyle, medical and familial factors associated with primary biliary cirrhosis. J Hepatol 2010, 53(1):162-169.

139. Gershwin ME, Selmi C, Worman HJ, Gold EB, Watnik M, Utts J, Lindor KD, Kaplan MM, Vierling JM: Risk factors and comorbidities in primary biliary cirrhosis: a controlled interview-based study of 1032 patients. Hepatology 2005, 42(5):1194-1202.

140. Prince MI, Ducker SJ, James OF: Case-control studies of risk factors for primary biliary cirrhosis in two United Kingdom populations. Gut 2010, 59(4):508-512.

141. Invernizzi P, Lleo A, Podda M: Interpreting serological tests in diagnosing autoimmune liver diseases. Semin Liver Dis 2007, 27(2):161-172.

142. Bogdanos DP, Invernizzi P, Mackay IR, Vergani D: Autoimmune liver serology: current diagnostic and clinical challenges. World J Gastroenterol 2008, 14(21):3374-3387.

143. Aoki CA, Roifman CM, Lian ZX, Bowlus CL, Norman GL, Shoenfeld Y, Mackay IR, Gershwin ME: IL-2 receptor alpha deficiency and features of primary biliary cirrhosis. J Autoimmun 2006, 27(1):50-53.

144. Wakabayashi K, Lian ZX, Moritoki Y, Lan RY, Tsuneyama K, Chuang YH, Yang GX, Ridgway W, Ueno Y, Ansari AA, et al: IL-2 receptor alpha(-/-) mice and the development of primary biliary cirrhosis. Hepatology 2006, 44(5):1240-1249.

145. Lan RY, Cheng C, Lian ZX, Tsuneyama K, Yang GX, Moritoki Y, Chuang YH, Nakamura T, Saito S, Shimoda S, et al: Liver-targeted and peripheral blood alterations of regulatory $T$ cells in primary biliary cirrhosis. Hepatology 2006, 43(4):729-737.

146. Hirschfield GM, Heathcote EJ, Gershwin ME: Pathogenesis of cholestatic liver disease and therapeutic approaches. Gastroenterology 2010, 139(5):1481-1496

\section{doi:10.1186/1471-230X-12-92}

Cite this article as: Invernizzi et al:: Autoimmune hepatitis type 2 associated with an unexpected and transient presence of primary biliary cirrhosis-specific antimitochondrial antibodies: a case study and review of the literature. BMC Gastroenterology 2012 12:92.

\section{Submit your next manuscript to BioMed Central and take full advantage of:}

- Convenient online submission

- Thorough peer review

- No space constraints or color figure charges

- Immediate publication on acceptance

- Inclusion in PubMed, CAS, Scopus and Google Scholar

- Research which is freely available for redistribution 